Article

\title{
Effects of Newcastle Disease Virus Strains AF2240 and V4-UPM on Cytolysis and Apoptosis of Leukemia Cell Lines
}

\author{
Aied M. Alabsi ${ }^{1,2,3, *}$, Siti Aishah Abu Bakar ${ }^{1}$, Rola Ali ${ }^{1}$, Abdul Rahman Omar ${ }^{4,5}$, \\ Mohd Hair Bejo ${ }^{4}$, Aini Ideris ${ }^{4}$ and Abdul Manaf Ali ${ }^{1}$ *
}

1 Department of Biotechnology, Faculty of Agriculture and Biotechnology, University Sultan Zainal Abidin (UniSZA), Terengganu 20400, Malaysia; E-Mails: sitiaishah@unisza.edu.my (S.A.A.B.); rola_absi@yahoo.com (R.A.)

2 Department of Cell and Molecular Biology, Faculty of Biotechnology and Biomolecular Sciences, University Putra Malaysia (UPM), Serdang 43300, Malaysia

3 Faculty of Dentistry, University of Malaya (UM), Kuala Lumpur, 50603, Malaysia

4 Faculty of Veterinary Medicine, University Putra Malaysia (UPM), Serdang 43300, Malaysia; E-Mails: aro@vet.upm.edu.my (A.R.O.); mdhair@vet.upm.edu.my (M.H.B.); aiini@vet.upm.edu.my (A.I.)

5 Institute of Bioscience, University Putra Malaysia (UPM), Serdang 43300, Malaysia

* Authors to whom correspondence should be addressed; E-Mails: aied_absi@yahoo.com (Ai.M.A.); manaf@unisza.edu.my (Ab.M.A.); Tel.: +60-96275510 (Ab.M.A.); Fax: +60-9221713 (Ab.M.A.).

Received: 14 September 2011; in revised form: 14 November 2011 / Accepted: 15 November 2011 / Published: 30 November 2011

\begin{abstract}
Newcastle disease virus (NDV) is used as an antineoplastic agent in clinical tumor therapy. It has prompted much interest as an anticancer agent because it can replicate up to 10,000 times better in human cancer cells than in most normal cells. This study was carried out to determine the oncolytic potential of NDV strain AF2240 and V4-UPM on WEHI-3B leukemia cell line. Results from MTT cytotoxicity assay showed that the $\mathrm{CD}_{50}$ values for both strains were 2 and 8 HAU for AF2240 and V4-UPM, respectively. In addition, bromodeoxyuridine (BrdU) and trypan blue dye exclusion assays showed inhibition in cell proliferation after different periods. Increase in the cellular level of caspase- 3 and detection of DNA laddering using agarose gel electrophoresis on treated cells with NDV confirmed that the mode of cell death was apoptosis. In addition, flow-cytometry analysis of cellular DNA content showed that the virus caused an increase in the sub-G1 region
\end{abstract}


(apoptosis peaks). In conclusion, NDV strains AF2240 and V4-UPM caused cytolytic effects against WEHI-3B leukemic cell line.

Keywords: NDV; cytolytic; apoptosis; flow-cytometry; leukemia

\section{Introduction}

Leukemia is a malignant neoplasm, characterized by neoplastic proliferation of hematopoietic cells, namely their diffuse replacement of the normal bone marrow [1,2]. Chemotherapeutic agents are used to prevent leukemic cells from multiplying, invading, metastasizing and finally killing the patient but they are very toxic and inhibit replication of both cancer and normal cells [3]. Over the past century, a series of case studies and anecdotal reports have indicated that viruses could indeed be used as anticancer therapeutics [4]. NDV is one of the nonengineered oncolytic viruses, which has a long history as a broad-spectrum oncolytic agent that can destroy tumor cells and stimulate the immune system [5]. NDV possesses several unique properties which make it an excellent anticancer agent; it has good cell binding properties, it binds specifically to tumor cells, it replicates selectively in tumor cell cytoplasm, it is relatively safe and it can act as an adjuvant [6]. It has oncolytic activity that can destroy tumor cells and stimulate the immune system. Many strains of NDV (73-T, MH68, Italian, Ulester, Rokin, PV701 and HUJ) have been shown to exhibit oncolytic activity [5,7]. In addition, the oncolytic effects of six Malaysian strains of NDV (AF2240, 01/C, Ijuk, S, F, and V4) have also been studied on several tumor cell lines [5,7]. However, no studies have yet been made using NDV oncolytic activity on myelomoncytic leukemia. Therefore, in this study the oncolytic effects of two Malaysian local NDV strains AF2240 and V4-UPM were tested in vitro against Mouse myelomoncytic leukemia cell line, WEHI-3B.

\section{Results}

\subsection{Cytotolytic Effects of NDV on Normal Cells and Myelomonocytic Leukemia Cells}

In this study, the cytolytic effects of Newcastle disease virus strains AF2240 and V4-UPM on mouse myelomonocytic leukemia (WEHI-3B), promyelocytic leukemia (HL-60) and T-lymphoblastoid leukemic (CEM-SS), normal mouse fibroblast (3T3), mouse spleen lymphocyte and A peripheral blood mononuclear cell (PBMC) were determined by measuring the cytotoxic dose that kill $50 \%$ of the cell population as compared to the untreated control for various periods using colorimetric cytotoxicity assay (MTT). The assay for each strain was repeated three times. Both AF2240 and V4-UPM strains showed cytolytic effect on WEHI-3B cell lines in dose-dependent manner. The titer of virus that killed $50 \%\left(\mathrm{CD}_{50}\right)$ of WEHI-3B cells, compared to untreated cells after $72 \mathrm{~h}$ of treatment were $2 \pm 0.2 \mathrm{HAU}$ and $8 \pm 0.2$ HAU (Haemagglutinating Units) for the AF2240 strain and V4-UPM strain, respectively. Furthermore, both NDV strains showed cytolytic effect on HL-60 and CEM-SS human leukemia cell lines (Table 1). On the other hand, AF2240 and V4-UPM strains showed low cytotoxic effect $\left(\mathrm{CD}_{50}\right)$ on normal mouse fibroblast (3T3), mouse spleen lymphocyte and peripheral blood mononuclear cell (PBMC) cells, which were used as normal cells (Table 1). 
Table 1. Cytotoxic effects dose $\left(\mathrm{CD}_{50}\right)$ of Newcastle disease virus strains (AF2240 and V4-UPM), in comparison with commercial drugs (doxorubicin and arabinocytocine) against leukemia and normal cell lines at $72 \mathrm{~h}$ of incubation.

\begin{tabular}{lcccc}
\hline Cell Lines & AF 2240 & V4-UPM & Doxorubicin & Arabinocytocine (Ara-C) \\
\hline WEHI-3B & $2 \pm 0.2$ & $8 \pm 0.2$ & $0.8 \pm 0.6$ & $1.0 \pm 0.13$ \\
HL-60 & $25 \pm 0.3$ & $110 \pm 0.8$ & $1.8 \pm 0.1$ & $0.3 \pm 0.05$ \\
CEM-SS & $16 \pm 0.6$ & $64 \pm 0.5$ & $3.5 \pm 0.1$ & $3.8 \pm 0.30$ \\
$3 T 3$ & NO CD 50 & NO CD 50 & $7.0 \pm 0.4$ & $2.8 \pm 0.20$ \\
PBMC & NO CD 50 & NO CD & $11.0 \pm 0.8$ & $7.0 \pm 0.80$ \\
$\begin{array}{l}\text { Mouse spleen } \\
\text { lymphocyte }\end{array}$ & NO CD & NO CD & & $4.5 \pm 0.2$ \\
\hline
\end{tabular}

\subsection{BrdU Cell Proliferation Assay}

The effects of NDV strains AF2240 and V4-UPM on cell proliferation of WEHI-3B cells based on the DNA synthesis phase were investigated using BrdU cell proliferation assay. This assay showed decrease in $570 \mathrm{~nm}$ optical density (OD) of WEHI-3B cells after treated with NDV strains AF2240 and V4-UPM in a time and concentration-dependent manner (Figure 1). As observed in Figure 1, untreated WEHI-3B cells exhibited an increase in OD from day 1 to 3 . However, the WEHI-3B cells treated with $\mathrm{CD}_{50}$ and $\mathrm{CD}_{75}$, showed decrease in OD from day 1 to 3.

Figure 1. BrdU Proliferation assay, effects of different concentrations of Newcastle disease virus (NDV) strains AF2240 (A) and V4-UPM (B) on the proliferation and viability of WEHI-3B cells.

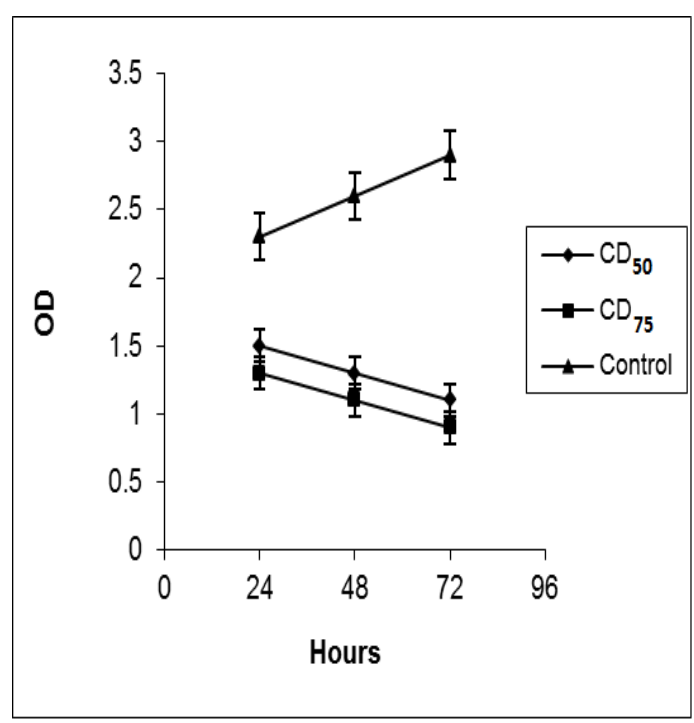

(A)

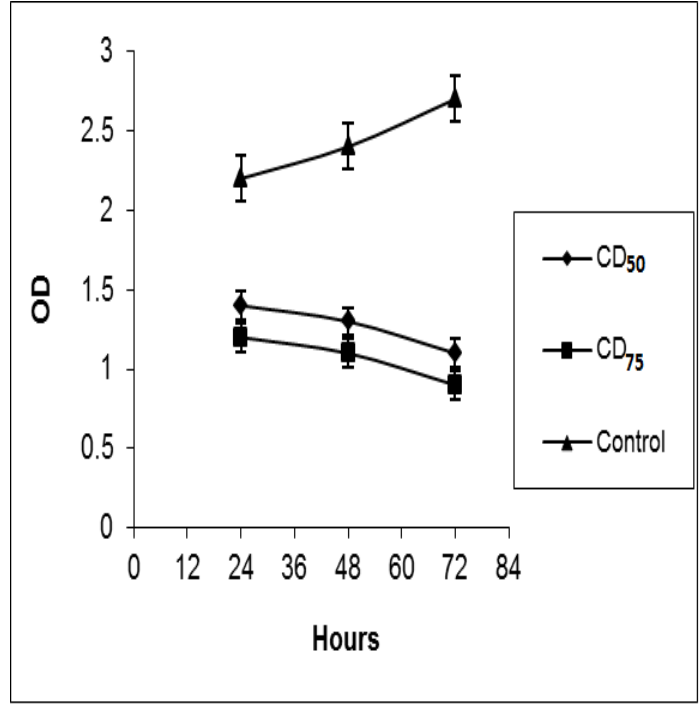

(B)

Similarly, as shown in the Figure 1, OD values in treated cells with $\mathrm{CD}_{75}$ decreased more than $\mathrm{CD}_{50}$ treatment until the third day. The decreased OD post treatment at both concentrations from first to third day was statistically significant $(p<0.05)$ when compared against the negative control. 


\subsection{Trypan Blue Exclusion Assay}

Based on the results of the trypan blue dye exclusion assay, increasing NDV exposure time had a significant effect on WEHI-3B cell viability. Treatment of WEHI-3B cells with $\mathrm{CD}_{50}$ and $\mathrm{CD}_{75}$ concentrations of virus strains ( 2 and $32 \mathrm{HAU}$ for AF2240 and 8 and 64 HAU for V4-UPM) resulted in a dose- and time-dependent inhibition of cell viability. As observed in Figure 2, at high concentration $\left(\mathrm{CD}_{75}\right)$ of AF2240, WEHI-3B cell viability reduced to $52 \%$ at $24 \mathrm{~h}$ as compared to the control and finally declined to $34 \%$ and $22 \%$ after 48 and $72 \mathrm{~h}$, respectively. At $\mathrm{CD}_{50}$ concentration of AF2240, WEHI-3B cell viability reduced to $78 \%$ at $24 \mathrm{~h}$ as compared to the control and finally reduced to $54 \%$ and $49 \%$ after 48 and $72 \mathrm{~h}$, respectively. On the other hand, at high concentration $\mathrm{CD}_{75}$ of V4-UPM, WEHI-3B cell viability reduced to $46 \%$ at $24 \mathrm{~h}$ as compared to the control and finally declined to $25 \%$ and $23 \%$ after 48 and $72 \mathrm{~h}$, respectively. Whereas, at $\mathrm{CD}_{50}$ concentration of V4-UPM, WEHI-3B cell viability reduced to $66 \%$ at $24 \mathrm{~h}$ compared to the control and finally declined to $56 \%$ and $50 \%$ after 48 and $72 \mathrm{~h}$, respectively.

Figure 2. Trypan blue exclusion assay. The percentage of viable cells in WEHI-3B cell population after treatment with different concentrations of virus strains at various time intervals.

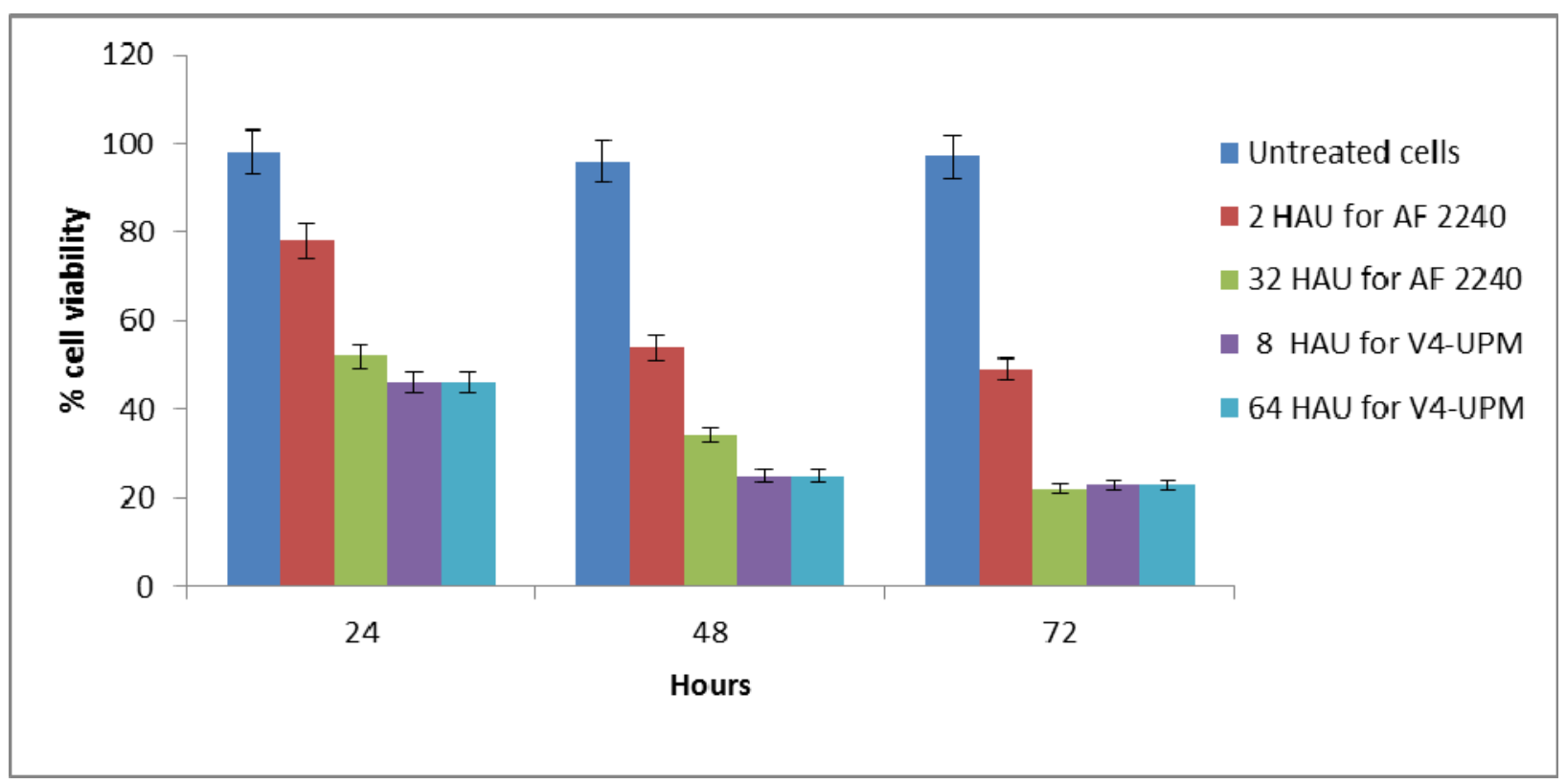

\subsection{DNA Fragmentation Assay}

Fragmentation of chromosomal DNA is the biological hallmark of apoptosis. During apoptotic cell death, cellular endonucleases cleave genomic DNA between nucleosides producing fragments whose lengths vary by multiples of 180-200 bp. When resolved using agarose gel electrophoresis, these DNA fragments appear as a nucleosomal ladder In this study, both NDV strains AF2240 and V4-UPM caused DNA fragmentation in WEHI-3B cells at $\mathrm{CD}_{50}$ values, 2 and 8 HAU for AF2240 and V4-UPM, after 24, 48 and $72 \mathrm{~h}$. DNA fragmentation of 180-200 base pairs multiples appeared as distinctive ladder-like pattern on an agarose gel (Figure 3). 
Figure 3. Agarose-gel-electrophoretic patterns showing DNA fragmentation of WEHI-3B cells treated with NDV strains AF2240 and V4-UPM at $\mathrm{CD}_{50}$ concentrations. From left to right: lane 1,7: 100 bp DNA markers; lane 2,8: WEHI-3B cell treated with doxorubicin (8 $\mu \mathrm{g} / \mathrm{mL})$; lane 3,9: untreated WEHI 3B cell; lane 4-6: WEHI-3B cell treated with AF2240 strain after 24, 48, and $72 \mathrm{~h}$, respectively; lane 10-12: WEHI-3B cell treated with V4-UPM strain after 24,48 , and $72 \mathrm{~h}$, respectively.

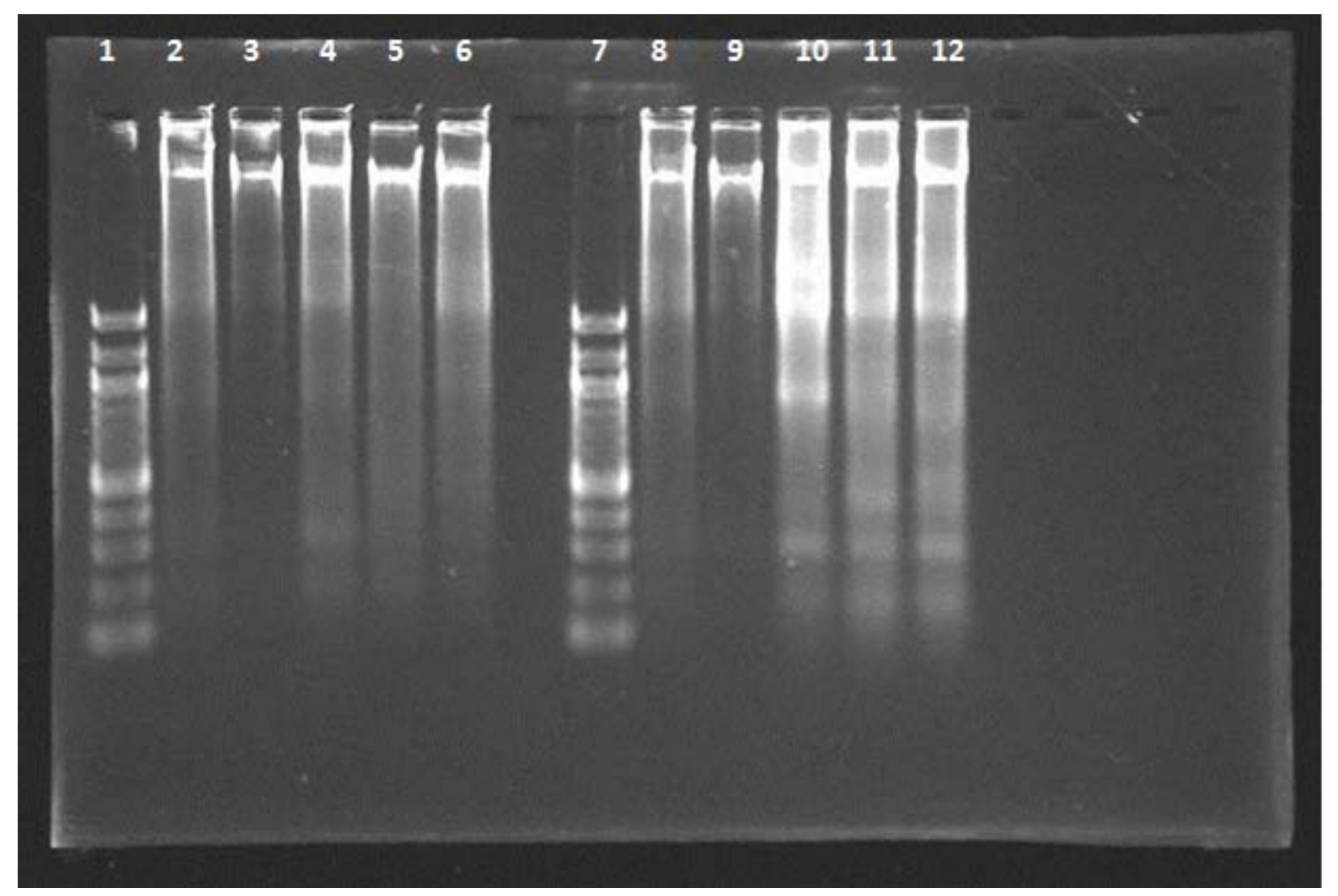

\subsection{Effects of NDV on Cell Cycle Distribution}

In this study, quantification of apoptosis on the basis of nuclear changes was performed by staining apoptotic nuclei with propidium iodide (PI). FACS analysis was used to study the cell cycle kinetics of NDV strains AF2240 and V4-UPM (CD ( $\left._{50}\right)$ on WEHI-3B cells, whereby 20,000 cells were analyzed using the Cell Quest Software. As shown in Figures 4, 5 and 6, after 24 h treatment with $\mathrm{CD}_{50}$ values of NDV strains AF2240 and V4-UPM, both virus strains were able to induce $14 \%$ and $13 \%$ of apoptotic cells of WEHI-3B cells population and the number of apoptotic cells started to increase gradually with time. After 48 and $72 \mathrm{~h}$ of treatment, NDV strain AF2240 was able to induce $18 \%$ and $21 \%$ of apoptotic cells (Figure 4A) while NDV strain V4-UPM able to induce $15 \%$ and $20 \%$ after 48 and $72 \mathrm{~h}$ (Figure 4B). There was a significant increase in apoptosis (Sub-G1) induction with time $(p<0.05)$ of WEHI-3B cell treated with both NDV strains compared to untreated cells. On the other hand both NDV strains showed no arrests of WEHI-3B cells at specific cell cycle phase, meaning NDV was able to kill WEHI-3B cells at different cell cycle stages. This virus-induced cell cycle perturbation concurred with the previous results, suggesting that WEHI-3B cells undergo apoptosis more extensively with increasing time. 
Figure 4. Flow-cytometry Cell cycle analysis of WEHI-3B cell population after staining with propidium iodide. (A) Cells treated with NDV strain AF2240 at $\mathrm{CD}_{50}$ value; (B) cells treated with NDV strain V4-UPM at $\mathrm{CD}_{50}$ value. Note: Each value represents of the mean of three replication \pm SEM, $(p<0.05)$.

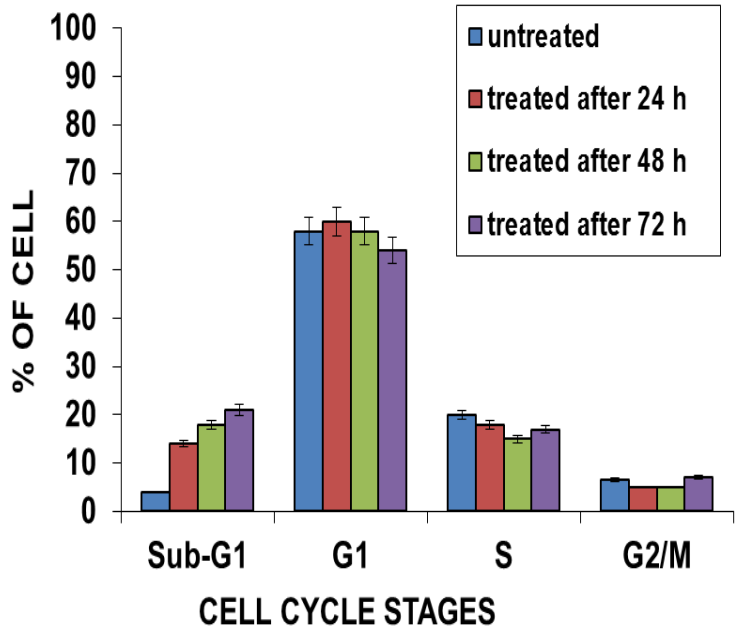

(A)

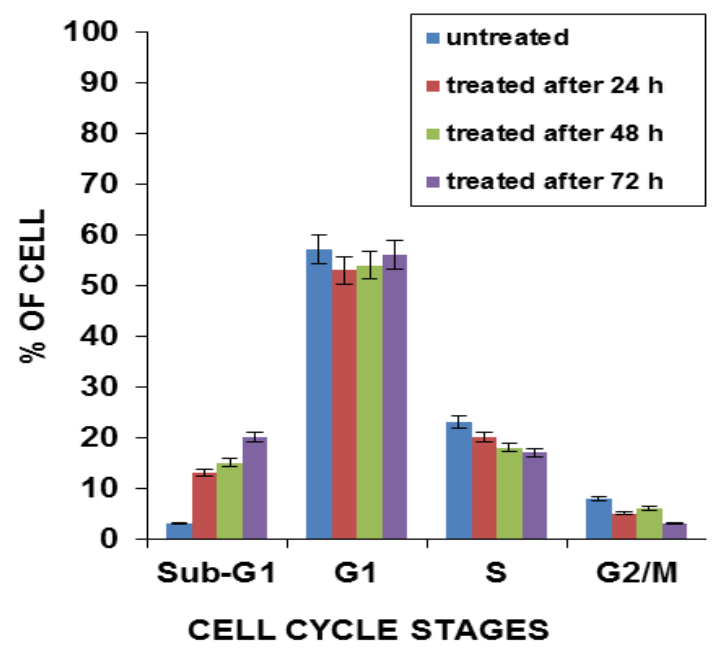

(B)

Figure 5. DNA fluorescence histograms of WEHI-3B cells treated with NDV strain AF2240 at CD $_{50}$ value (a) untreated cells; (b) cells treated after $24 \mathrm{~h}$; (c) cells treated after 48 h; (d) cells treated after 72 h. (B) Sub-G1; (C) G1; (D) S; and (E) G2/M.

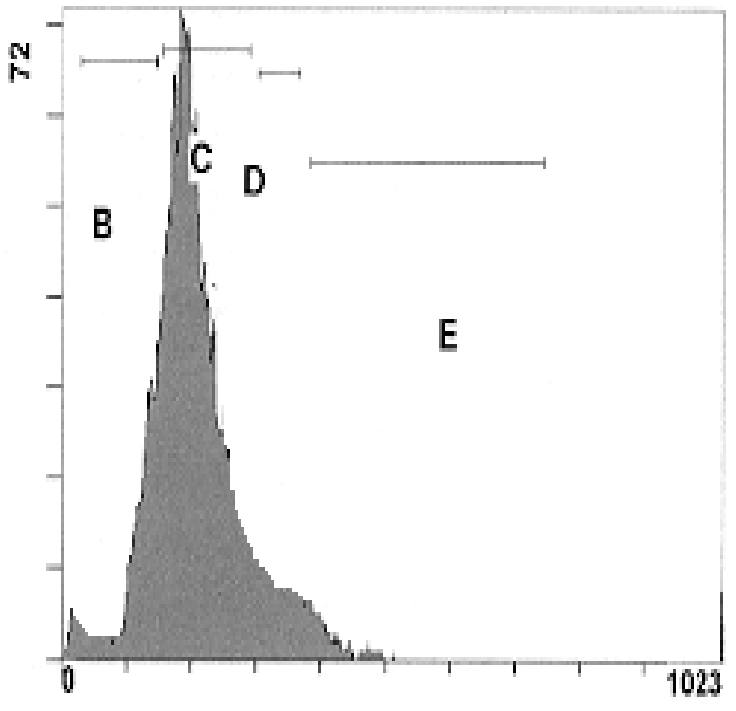

FL2 Lin

(a)

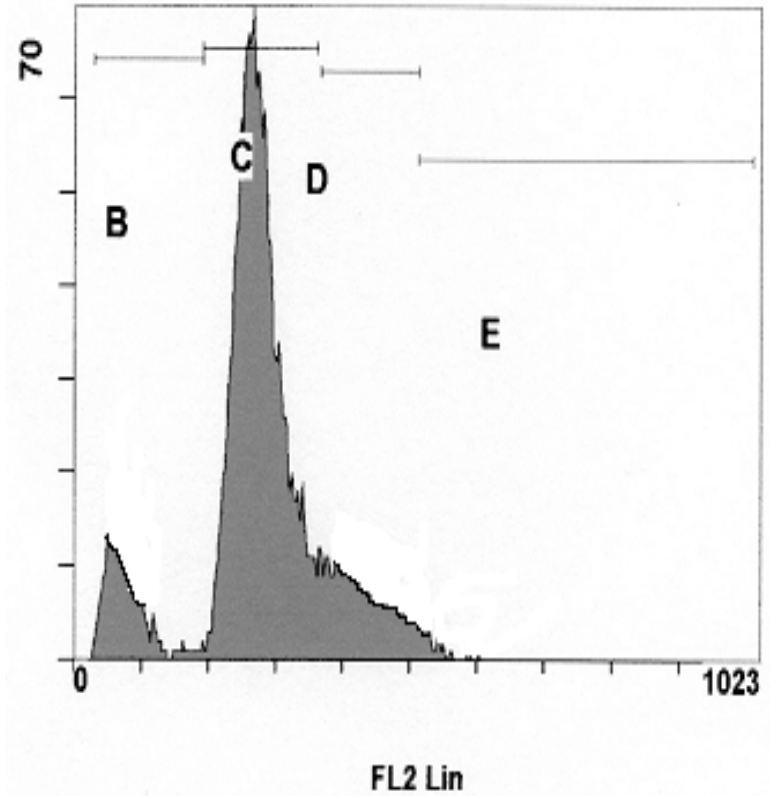

(b) 
Figure 5. Cont.

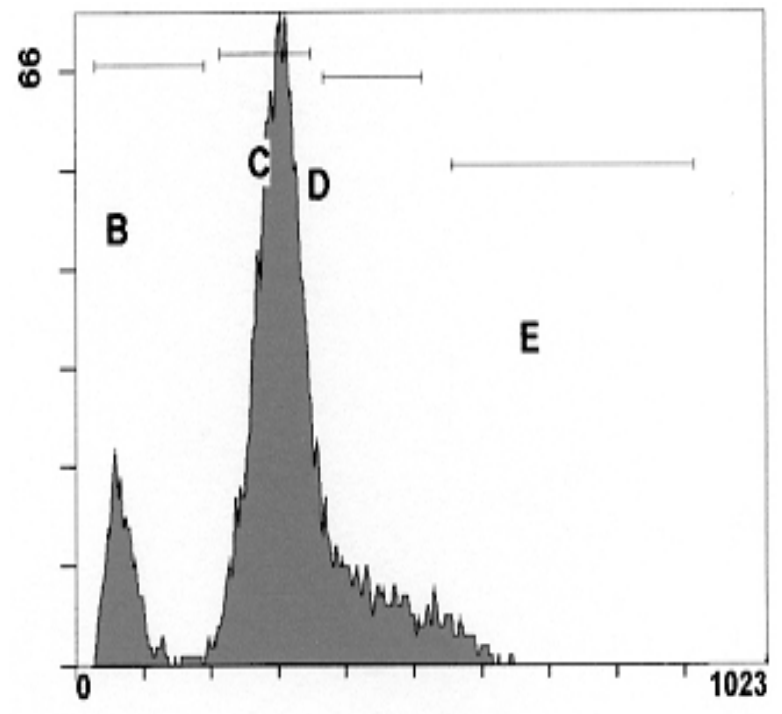

FL2 Lin

(c)

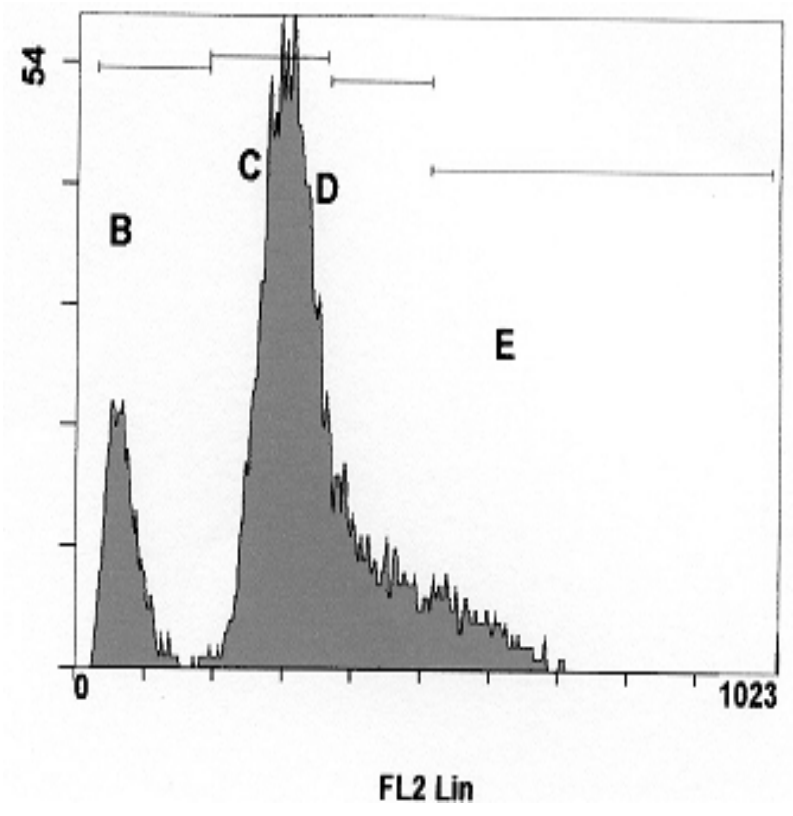

(d)

Figure 6. DNA fluorescence histograms of WEHI-3B cells treated with NDV strain V4-UPM at $\mathrm{CD}_{50}$ value (a) untreated cells; (b) cells treated after $24 \mathrm{~h}$; (c) cells treated after 48 h; (d) cells treated after 72 h. (B) Sub-G1; (C) G1; (D) S; and (E) G2/M.

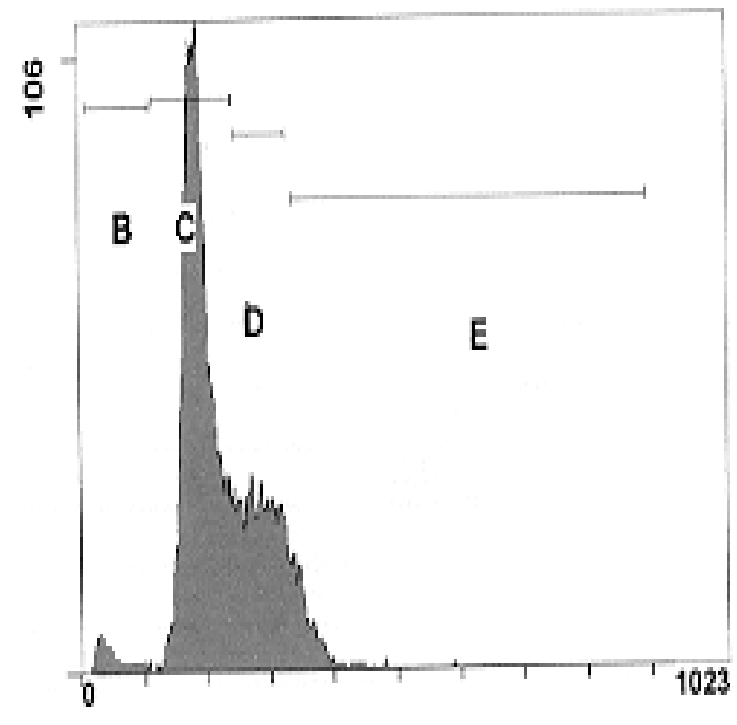

FL2 Lin

(a)

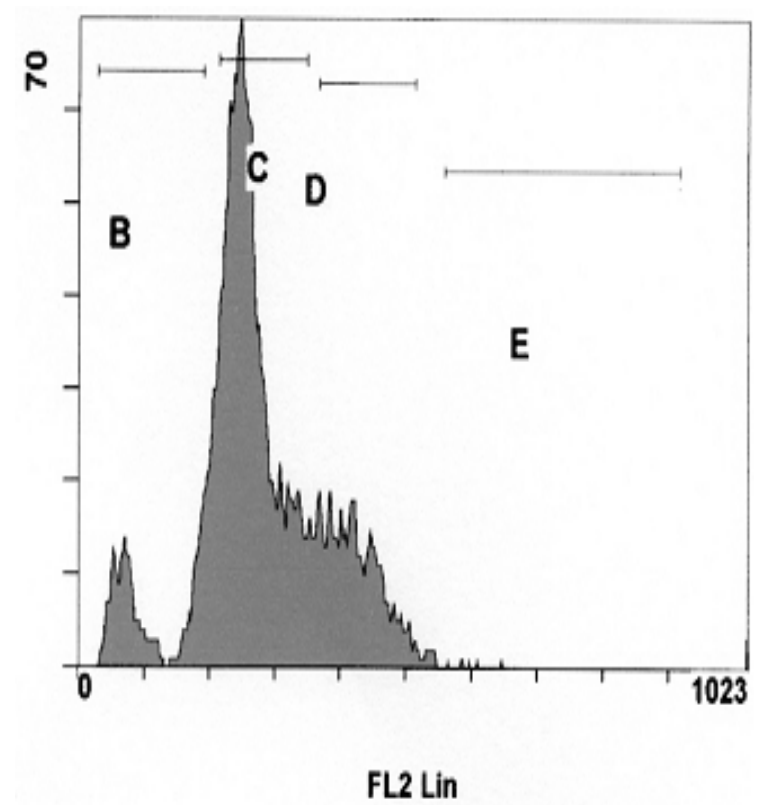

(b) 
Figure 6. Cont.

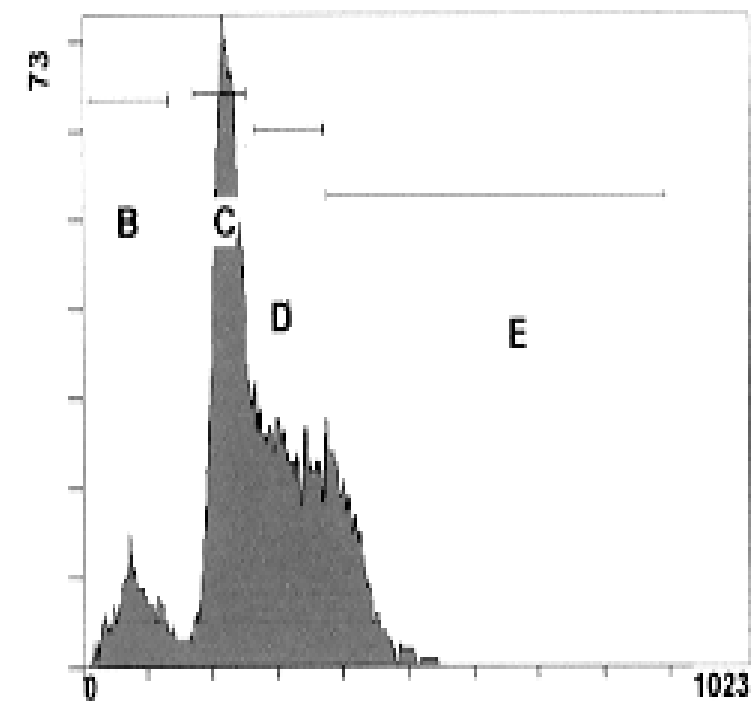

FL 2 LIII

(c)

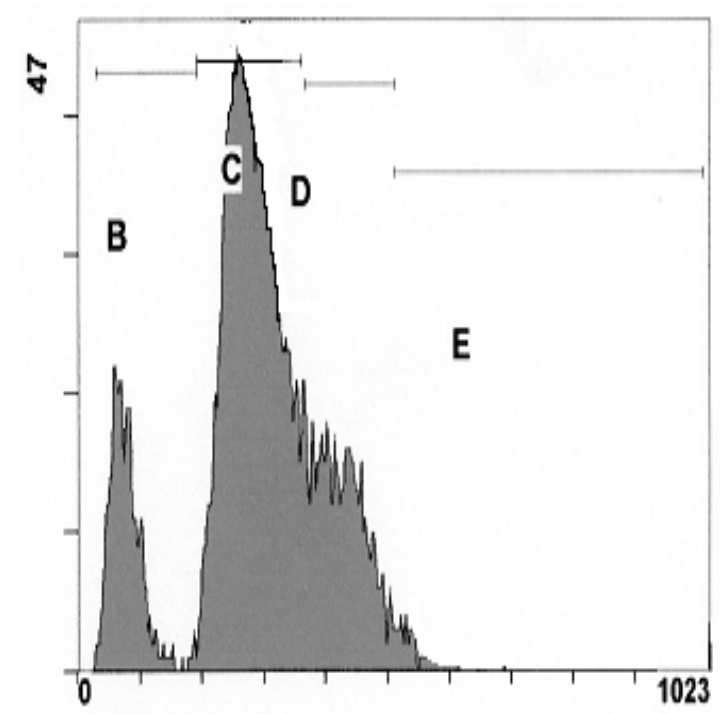

FL2 Lin

(d)

\subsection{Activation of Caspase-8, an Initiator Caspase for the Extrinsic Pathway}

The involvement of caspase- 8 in response to the treatment of NDV was determined. Treatment for $12 \mathrm{~h}$ activated caspase- 8 at $26.8 \%$ and increased to $59.1 \%$ at $24 \mathrm{~h}$ post-treatment (Figure $7 \mathrm{~A}$ ).

Figure 7. Effects of NDV on caspase 8 (A), caspase 9 (B) and caspase 3/7 (C) in WEHI-3B cells. Data were expressed as mean \pm SEM of three experiments $(n=3)$. Significant differences from untreated control are indicated by $p<0.05$.

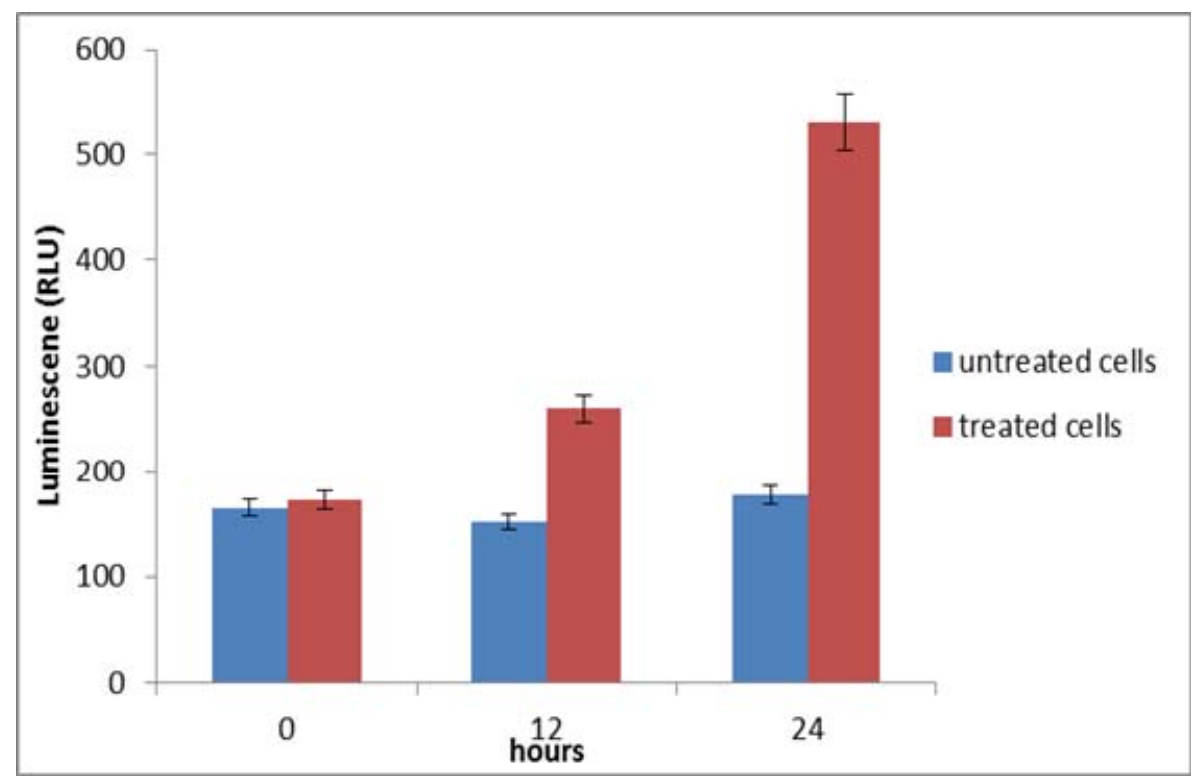

(A) 
Figure 7. Cont.

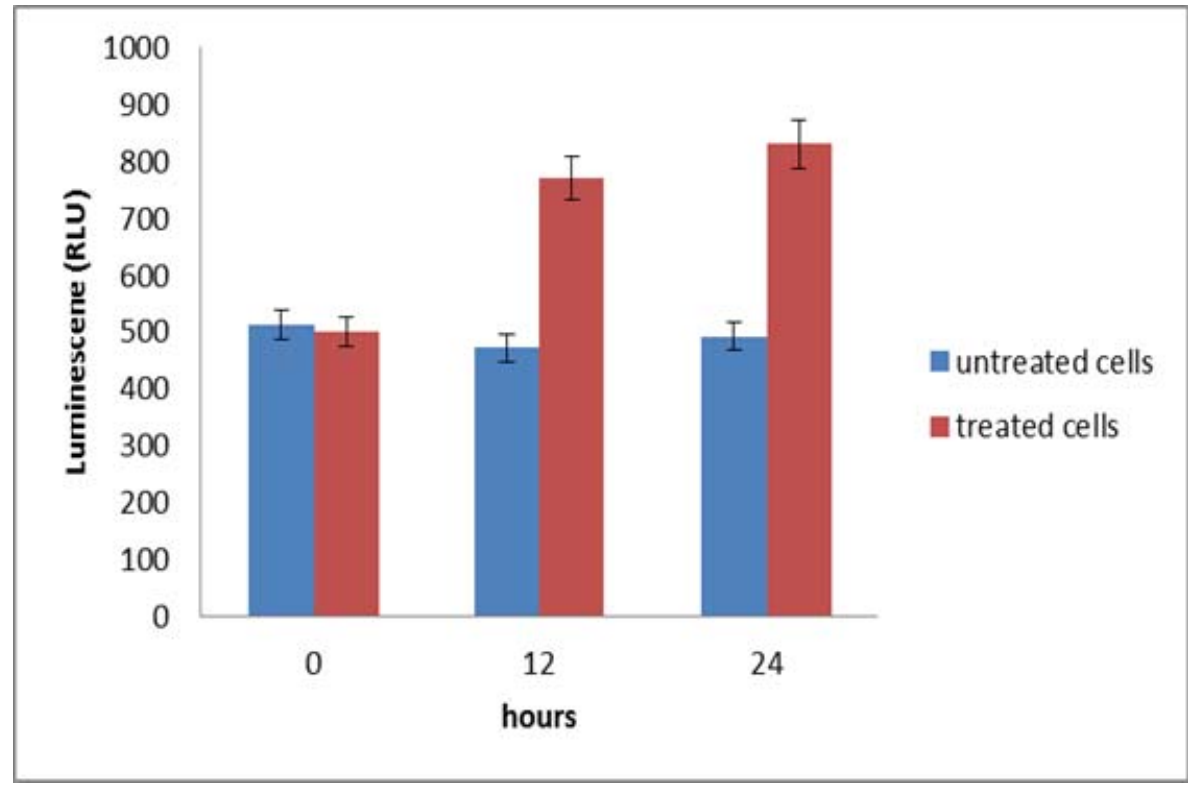

(B)

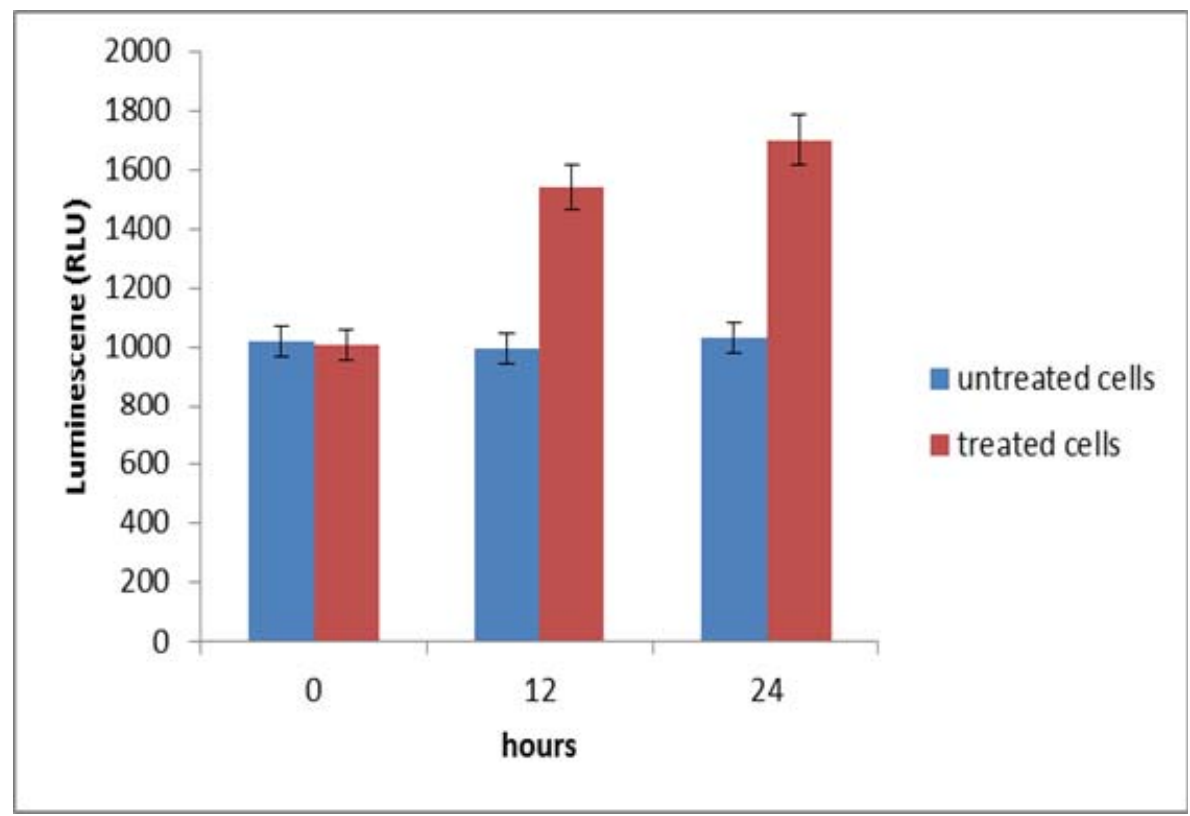

(C)

\subsection{Activation of Caspase-9, an Initiator Caspase for the Intrinsic Pathway}

The involvement of caspase-9 in response to the treatment of NDV was also examined. As shown in Figure 7B, there was a gradual increase (from 12 to $24 \mathrm{~h}$ ) of caspase-9 activation at 46.5 and $55.8 \%$, respectively.

\subsection{Activation of Effector/Executioner Caspases (Caspase-3/7)}

The involvement of effector caspase, caspase-3/7 in response to the treatment of NDV was further determined. Treatment of WEHI-3B cells with NDV for $12 \mathrm{~h}$ activated caspase-3/7 at $42.67 \%$ and increased to $78.4 \%$ at $24 \mathrm{~h}$ post-treatment (Figure $7 \mathrm{C}$ ). 


\section{Materials and Methods}

\subsection{Propagation and Purification of NDV Strains AF2240 and V4-UPM}

NDV was propagated in allantoic fluid of 9-11 days-old embryonated chicken eggs at $37{ }^{\circ} \mathrm{C}$ for $48 \mathrm{~h}$. The allantoic fluid was harvested and the presence of virus was confirmed by the haemaglutination test [8]. NDV purified as previously described by Chambers and Samson (1980) [9].

\subsection{Cells and Cell Culture}

(WEHI-3B) murine myelomoncytic leukemia cell line and 3T3 (Mouse fibroblast) cell lines were provided by the Laboratory of Molecular and Cell Biology, Institute of Bioscience, Universiti Putra Malaysia. WEHI-3B and 3T3 cell lines were cultured in DMEM (Sigma, USA) containing 10\% fetal bovine serum (FBS), $100 \mathrm{U} / \mathrm{mL}$ penicillin and $100 \mu \mathrm{g} / \mathrm{mL}$ streptomycin at $37{ }^{\circ} \mathrm{C}$ in a humidified atmosphere of $5 \% \mathrm{CO}_{2}$ in air. The cells were grown to confluence and sub-cultured at three to four days interval before the experiments.

\subsection{Cell Viability and Proliferation Assessment}

\subsubsection{MTT Cytotoxicity Assay}

Leukemia cells inhibition by NDV was measured using Microtitration cytotoxicity [10,11]. About $150 \mu \mathrm{L}$ complete medium were added into of flat-bottom 96-well plate (Nunclon ${ }^{\mathrm{TM}}$, Denmark) and $50 \mu \mathrm{L}$ of the 2-folded serial virus dilution were added into the wells. In the last well, $50 \mu \mathrm{L}$ of PBS were added instead of the virus, which represented as control. Then $50 \mu \mathrm{L}$ of $5 \times 10^{5}$ cells of CEM-SS (human T-lymphobalstic leukemia), WEHI-3B (Mouse Myelomoncytic leukemia), HL-60 (Promyelocytic leukemia), were added to top up the final volume to $200 \mu \mathrm{L}$ and the plate was incubated at $37^{\circ} \mathrm{C}$ in an atmosphere of $5 \% \mathrm{CO}_{2}$. Seventy-two hours later, $20 \mu \mathrm{L}$ of MTT $(5 \mathrm{mg} / \mathrm{mL})$ in PBS solution was added to each well then the plate was further incubated for $4 \mathrm{~h}$. Most of the medium was removed and $100 \mu \mathrm{L}$ of DMSO (dimethyl sulfoxide) was added into the wells to soluble the crystals. Finally the OD was measured by (ELISA) reader at wavelength of $570 \mathrm{~nm}$. Then graphs of percentage of viable cells versus virus titer $\mathrm{HAU}$ were plotted. The value of $\mathrm{CD}_{50}$ was determined from the graphs obtained at the concentration that cause $50 \%$ cell reduction as compared with controls.

\subsubsection{BrdU Proliferation Assay}

The BrdU proliferation assay for treated and untreated WEHI-3B cells was carried out using a kit BrdU Cell Proliferation assay (CHEMICON, USA). WEHI-3B cells at concentration of $1 \times 10^{5}$ cells $/ \mathrm{mL}$ treated with both NDV strains at $\mathrm{CD}_{50}$ and $\mathrm{CD}_{75}$ concentrations ( 2 and $32 \mathrm{HAU}$ for AF2240 and 8 and $64 \mathrm{HAU}$ for V4-UPM). Then the plates were incubated in an atmosphere of $5 \% \mathrm{CO}_{2}$ at $37{ }^{\circ} \mathrm{C}$ for 24 , 48 and $72 \mathrm{~h}$. After incubation periods, the cells were washed with PBS twice. Further procedure was done according to protocol specified by the manufacturer. The plates were read using a spectrophotometer microplate reader at dual wavelength of $450 \mathrm{~nm}$ and $550 \mathrm{~nm}$. The OD of samples was plotted against time to determine the growth rates of cells in a given value. 


\subsubsection{Trypan Blue Exclusion Assay}

Trypan Blue Exclusion assay was employed to determine the number of viable cells in cultures. The cells were incubated with different $\mathrm{CD}_{50}$ and $\mathrm{CD}_{75}$ concentrations of both NDV strains ( 2 and $32 \mathrm{HAU}$ for AF2240 and 8 and $64 \mathrm{HAU}$ for V4-UPM) at $37^{\circ} \mathrm{C}$. The viability of the cells was then determined at the designated time interval. Cells were analyzed by viable cell counts and the percentage of cell viability was obtained. The results were expressed as the mean percentage of cell viability \pm SEM of triplicate cultures.

\subsection{DNA Fragmentation Assay}

Cells at a concentration of $5 \times 10^{6}$ cells $/ \mathrm{mL}$ were seeded into 6-well plate (Nunclon ${ }^{\mathrm{TM}}$, Denmark) in $2 \mathrm{~mL}$ culture medium with a concentration of $\mathrm{CD}_{50}$ value of viruses. Some wells were left with no virus to be used as a control. After the $72 \mathrm{~h}$ of incubation, cells were spun down at $1000 \mathrm{rpm}$ for $10 \mathrm{~min}$ and the pellet was washed with PBS twice. The DNA extraction from treated and untreated cells was carried out according to protocol of a kit for Blood and Cultured Cells from QIAGEN. The purified DNA was subjected to electrophoresis in $1.5 \%$ agarose gel. The gel was electrophoresed for and stained in ethidium bromide. The bands were visualized using UV light transillumintor.

\subsection{Analysis of Cellular DNA Content Using Propidium Iodide}

Cells at a concentration of $5 \times 10^{6}$ cells $/ \mathrm{mL}$ of WEHI-3B cell line was incubated in 6-well plate in with a concentration of $\mathrm{CD}_{50}$ value of virus for $72 \mathrm{~h}$. Some wells were left with no virus to be used as a control. After the incubation period, the Cells were fixed by adding $500 \mu \mathrm{L}$ of $80 \%$ cold ethanol and kept for at least $2 \mathrm{~h}$ at $-20{ }^{\circ} \mathrm{C}$. Cells were pelleted at $1000 \mathrm{rpm}$ for $10 \mathrm{~min}$ and the ethanol was discarded. The cell pellet was washed with $1 \mathrm{~mL}$ (PBS/sodium azide) twice. The pellet was resuspended with $1 \mathrm{~mL}$ of (PBS $+0.1 \%$ triton X-100 $+10 \mathrm{~mm}$ EDTA $+50 \mu \mathrm{g} / \mathrm{mL}$ RNase $+2 \mu \mathrm{g} / \mathrm{mL}$ Propidium iodide) followed by incubated for $1 / 2$ to $1 \mathrm{~h}$ at $4^{\circ} \mathrm{C}$. Finally, samples were analyzed by flow cytometer (Beckman Coulter, USA).

\subsection{Analysis of Caspase-3/7, 8 and 9 Activities}

Caspase-3/7, 8 and 9 activities was measured using Caspase-Glo ${ }^{\circledR}$ 3/7, 8 and 9 Assay Kit (Promega, USA). The kit provided a lumigenic caspase-3/7, 8 and 9 substrates, in a reagent optimized for caspase activity, luciferase activity and cell lysis. Cells of WEHI-3B were grown in white-wall, optical bottom 96-well plate and treated with NDV at $\mathrm{CD}_{50}$ for 0,12 and $24 \mathrm{~h}$. After the incubation time, an equal volume of the reagent were added to the cells and further incubated for $1 \mathrm{~h}$. The contents were mixed gently using a plate shaker at 300 to $500 \mathrm{rpm}$ for $30 \mathrm{~s}$. Luminescene plate reader, Tecan (Infinite M200) was used to measure luminescene intensity. Blank values were subtracted from experimental values. 


\subsection{Statistical Analysis}

Data was expressed as mean \pm SEM. Statistical analysis was performed with Student's $t$-test for data from MTT cytotoxicity assay, BrdU Proliferation Assay, Trypan blue exclusion assay, flowcytometry and caspases with $\mathrm{p}$ value of less than 0.05 .

\section{Discussions}

Oncolytic viruses are viruses that infect and replicate in cancer cells, destroying these harmful cells and leaving normal cells largely unaffected. NDV is an oncolytic virus with the ability to induce tumor lysis through different mechanisms [12] and it appears to replicate and kill tumor cells but not normal human cells [13]. Development of biologically targeted agents that exploit differences between cancerous and normal cells and permit greater specificity for cancer cells with less damage to normal cells is still the ultimate goal in the field of antineoplastic drug discovery [14]. This study showed that NDV AF2240 and V4-UPM strains have the ability to induce cytolysis, apoptosis and anti-proliferation in (WEHI-3B) murine myelomoncytic leukemia cell line.

Based on the MTT assay, treatment with both NDV strains resulted in concentration- and time-dependent cytolyitic effects on the WEHI-3B cells but not on mouse fibroblast (3T3), mouse spleen lymphocyte and peripheral blood lymphocyte cells, which were used as normal cells. These results complies with previous other studies [7,15-18] which stated that the effectiveness of NDV strains AF2240 and V4 UPM as an oncolytic agent was found on breast cancer cell lines (MCF-7 and MDA-231), leukemia cell lines (HL-60 and CEM-SS) and brain tumor cell line (DBTRG.5MG and U87MG).

To further investigate the cytolytic effects of the virus, inhibition of WEHI-3B proliferation was determined using the bromodeoxyuridine (BrdU) cell proliferation assay, which is based on the DNA synthesis phase [19]. Inoculation of both NDV strains on the WEHI-3B cells with high titre showed that the growth rates of the cells decreased more than those inoculated with low titre. On the other hand, untreated WEHI-3B cells exhibited an increase in the growth rates. Therefore, both NDV strains were able to inhibit WEHI-3B cell proliferation.

The trypan-blue exclusion test also showed that NDV has significant antiproliferative effects on WEHI-3B cells. This test is based on the principle that living cells possess intact cell membranes that exelude the dye, whereas dead cells do not [20].

Apoptosis is particularly relevant to viral pathogenesis; it is a major mechanism for viral clearance by the mammalian immune system which induces apoptosis in infected cells. It is becoming increasingly apparent that many viruses have evolved proteins that are capable of attenuating apoptosis [21]. A number of methods have been used by researchers to distinguish between apoptosis and necrosis. In this study we reported that both NDV strains stimulate DNA fragmentation characteristic of apoptosis in WEHI-3B cell line at 24, 48 and $72 \mathrm{~h}$ post-inoculation. Internucleosomal cleavage of DNA is likely to be in the later phase of apoptotic process [22-24]. The DNA ladder assay is generally accepted as specific for apoptosis because it detects oligonucleosomal cleavage rather than artificial DNA cleavage or necrosis. To date, apoptosis has been characterized biochemically by the 
production of 180-200 bp internucleosomal DNA fragments resulting from the activation of an endonuclease [23].

Further confirmation of the mode of cell death was carried out by Flow cytometric analysis of cell cycle which is a rapid and quantitative measure on apoptotic changes cells by staining with DNA dyes [25]. This method is useful for quantitative estimates of the fractions of cells in the different phases of the cell cycle [26]. Untreated and treated WEHI-3B cell lines were evaluated for apoptosis by measuring the amount of apoptotic cells using of DNA flow cytometry (FCM). In the present study, we found that an apoptotic peak appeared before the G1 phase when WEHI-3B cells were treated with both NDV strains. Both NDV strains caused an increase in the $\mathrm{subG}_{1}$ region which increased of time. This time-dependent effect was significantly apparent upon the induction of apoptosis, with no induction of cell cycle arrest in any specific phase. The fluorescence histograms showed that there were less of treated WEHI-3B cells in all three phases of the cell cycle $\left(G_{1}, S\right.$ and $\left.G_{2} / M\right)$ accompanied by a large increase in the sub-G1 region (apoptosis peak).

Caspases are effectors and executioners. The effector caspases can be activated by multiple pathways, some involving the mitochondria and others independent of this organelle. Once effector caspases become active, they cleave and activate the downstream executioner caspases. These downstream caspases then cleave and activate a series of molecules, which are involved in terminal apoptotic events. Without proper functioning caspases, the upstream tumor-suppressor genes may be unable to activate the apoptotic pathway. Therefore, caspases are an important indicator for tumor therapy. In this study, Caspase- 8 was identified as an initiator caspase triggered by death receptors. So, the activation of caspase-8 suggested that NDV might induce apoptosis through the extrinsic death receptor-pathway. Death receptors are cell-surface cytokine receptors belonging to the tumor necrosis factor (TNF) receptor superfamily that trigger apoptosis after binding to a group of structurally related ligands or specific antibodies [27-29]. The activation of caspase-9 in NDV-treated WEHI-3B cells can be related with the involvement of mitochondria. Mitochondria act as important sensors of cellular damage. Any increase in the permeability of the outer mitochondrial membrane can allow certain proteins, such as cytochrome $c$, to be released from the mitochondrial intermembrane space into the cytosol and activate the apoptosome. Upon activation within the apoptosome, caspase-9 then propagates the caspase cascade through activation of caspases- 3 and -7 . Caspase- 3 in turn activates caspases- 2 and -6 and then promotes activation of the downstream caspases-8 and -10 [30]. Caspase-3 also participates in a feedback amplification loop to further process caspase-9 [31]. Thus, it is evident that once caspase-9 is activated within the apoptosome, there is a rapid amplification of the death signal through the activation of a panoply of other caspases . The executioner caspase include caspases-3, -6 and -7 . Many studies have suggested that caspase- 3 is the primary executioner caspase with relatively few physiological substrates for caspases- 6 and -7 [32]. It is assumed that caspase- 3 has a position as a central executioner caspase in mammals and the role of caspase- 3 is supported by the convergence of both death-receptor and mitochondrial-mediated death pathways at caspase- 3 activation as well as by the wide range of potential caspase-3 substrates [33,34].

As a conclusion, we investigated the use of NDV strains AF2240 and V4-UPM as an oncolytic agent of WEHI-3B myelomoncytic leukemia cells. Our study suggests that the NDV have a potent effect on leukemia cells and that its cytotoxicity increases with increasing titers of the virus. NDV was also found to act by inducing apoptosis in the WEHI-3B leukemia cells. 


\section{Acknowledgments}

This research was funded in part by the National Cancer Council (MAKNA), Malaysia. The authors also acknowledge additional support from Universiti Putra Malaysia (UPM), Short Term Research Grant from Universiti Sultan Sultan Zainal Abidin (UNISZA) and Fundamental Research Grant Scheme (FRGS) from the Ministry of Higher Education of Malaysia.

\section{References}

1. Cotran, R.S.; Kumar, V.; Robbin, S.L. Neoplasia. In Robbin's Pathologyical Basis of Diseases, 5th ed.; Saunders: Philiadelphia, PA, USA, 1994; pp. 241-303, 649-658.

2. Hughes-Jones, N.C.; Wickramasinghe, S.N. Acute and Chronic Leukemia. In Lecture Notes on Haematology, 6th ed.; Blackwell Science Ltd.: Paris, France, 1996; pp. 134-160.

3. Zuco, V.; Rhigetti, S.C.; Cleris, E.; Marchesi, L.; Passerini, C.G.; Formelli, F. Selective cytotoxicity of betulinic acid on tumor cell lines but not normal cells. Cancer Lett. 2002, 175, 17-25.

4. Parato, K.A.; Senger, D.; Forsyth, P.A.J.; Bell, J.C. Recent progress in the battle between oncolytic viruses and tumours. Nature 2005, 5, 965-976.

5. Freeman, A.I.; Zakay-Rones, Z.; Gomori, J.M.; Linetsky, E.; Rasooly, L.; Greenbaum, E.; Rozenman-Yair, S.; Panet, A.; Libson, E.; Irving, C.S.; Galun, E.; Siegal, T. Phase I/II trial of intravenous NDV-HUJ oncolytic virus in recurrent glioblastoma multiforme. Mol. Ther. 2006, 13, 221-228.

6. Schirrmacher, V.; Ahlert, T.; Pröbstle, T.; Steiner, H.H.; Herold-Mende, C.; Gerhards, R.; Hagmüller, E.; Steiner, H.H. Immunization with virus-modified tumor cells. Semin. Oncol. 1998, 25, 677-696.

7. Omar, A.; Aini, I.; Ali, A.; Othman, F.; Yusoff, K.; Abdullah, J.M.; Wali, H.; Zawawi, M.; Meyyappan, N. An overview on the development of Newcastle disease virus as an anti-cancer therapy. Malays. J. Med. Sci. 2003, 10, 4-12.

8. Alexander, D.J. Newcastle Disease. In Newcastle Disease Virus an Avian Paramyxovirus; Kluwer Academic Publishers: Dordrecht, The Netherlands, 1988; pp. 1-22.

9. Yusoff, K.; Tan, W.S.; Lau, C.H.; Ng, B.K.; Ibrahim, A.L. Sequence of the haemagglutininneuraminadase gene of the Newcastle disease virus oral vaccine strain V4 (UPM). Avian Pathol. 1996, 25, 837-844.

10. Mosmann, T. Rapid Colorimetric Assay for cellular growth and survival: Application to proliferation and cytotoxicity assays. J. Immunol. Methods 1983, 65, 55-63.

11. Pujalté, I.; Passagne, I.; Brouillaud, B.; Tréguer, M.; Durand, E.; Ohayon-Courtès, C.; L’Azou1, B. Cytotoxicity and oxidative stress induced by different metallic nanoparticles on human kidney cells. Part. Fibre Toxicol. 2011, 8, 10:1-10:16.

12. Szeberenyi, J.; Fabian, Z.; Torocsik, B.; Kiss, K.; Csatary, L.K. Newcastle disease virus-induced apoptosis in PC12 pheochromocytoma cells. Am. J. Ther. 2003, 10, 282-288.

13. Reichard, K.W.; Lorence, R.M.; Cascino, C.J.; Peeples, M.E.; Walter, R.J.; Fernando, M.B.; Reyes, H.M.; Greager, J.A. Newcastle disease virus selectively kills human tumor cells. J. Surg. Res. 1992, 52, 448-453. 
14. Adams, J. Proteasome inhibition in cancer: Development of PS-341. Semin. Oncol. 2001, 28, 613-619.

15. Zulkifli, M.M.; Ibrahim, R.; Ali, A.M.; Aini, I.; Jaafar, H.; Hilda, S.S.; Alitheen, N.B.; Abdullah, J.M. Newcastle diseases virus strain V4UPM displayed oncolytic ability against experimental human malignant glioma. Neurol. Res. 2009, 13, 3-10.

16. Othman, F.; Ideris, A.; Motalleb, G.; Eshak, Z.B.; Rahmat, A. Oncolytic effect of newcastle disease virus AF2240 strain on the MCF-7 breast cancer cell line. Yakhteh Med. J. 2010, 12, $17-24$.

17. Ali, R.; Alabsi, A.M.; Ali, A.M.; Ainideris; Omar, A.R.; Yousoff, K. Apoptosis induction and cytolytic effects of newcastle disease virus strain AF2240 on DBTRG.05 mg brain tumor cell line. Int. J. Cancer Res. 2011, 7, 25-35.

18. Ali, R.; Alabsi, A.M.; Ali, A.M.; Ideris, A.; Omar, A.R.; Yusoff, K.; Saif-Ali, R. Cytolytic effects and apoptosis induction of newcastle disease virus strain AF2240 on anaplastic astrocytoma brain tumor cell line. Neurochem. Res. 2011, 36, 2051-2062.

19. Ruben, R.L.; Neubuer, R.H. Semiautomated colorimeteric assay for in vitro screening of anticancer compounds. Cancer Treat. Rep. 1987, 71, 1141-1149.

20. Strober, W. Trypan Blue Exclusion Test of Cell Viability. In Current Protocols in Immunology; Coligan, J.E., Kruisbeek, A.M., Margulies, D.H., Shevach, W.M., Strober, W., Eds.; John Wiley and Sons, Inc.: Hoboken, NJ, USA, 2003.

21. Muneesh, T.; Vishva, M.D. Fas- and tumor necrosis factor-induced apoptosis is inhibited by the poxvirus crmA gene product. Am. Soc. Biochem. Mol. Biol. 1995, 270, 3255-3260.

22. Cohen, G.M.; Sun, X.M.; Snowden, R.T.; Dinsdale, D.; Skilleter, D.N. Key morphological features of apoptosis may occur in the absence of internucleosomal DNA fragmentation. Biochem. J. 1992, 286, 331-334.

23. Oberhammer, F.; Wilson, J.W.; Dive, C.; Morris, I.D.; Hickman, J.A.; Wakeling, A.E.; Walker, P.R.; Sikorska, M. Apoptotic death in epithelial cells: Cleavage of DNA to 300 and/or $50 \mathrm{~kb}$ fragments prior to or in the absence of internucleosomal fragmentation. EMBO J. 1993, 12, 3679-3684.

24. Gooch, J.L.; Yee, D. Strain-specific differences in formation of apoptotic DNA ladders in MCF-7 breast cancer cells. Cancer Lett. 1999, 144, 31-37.

25. Telford, W.G.; King, L.E.; Fraker, P.J. Rapid quantitation of apoptosis in pure and heterogeneous cell populations using flow cytometry. J. Immunol. Methods 1994, 172, 1-16.

26. Fried, J.; Perez, A.G.; Clarkson, B.D. Flow cytofluorometric analysis of cell cycle distributions using propidium iodide, Properties of the method and mathematical analysis of the data. J. Cell Biol. 1976, 71, 172-181.

27. Nagata, S. Apoptosis by death factor. Cell 1997, 88, 355-365.

28. Ashkenazi, A.; Dixit, V.M. Death receptors: Signaling and modulation. Science 1998, 281, 1305-1308.

29. Locksley, R.M.; Killeen, N.; Lenardo, M.J. The TNF and TNF receptor superfamilies: Integrating mammalian biology. Cell 2001, 104, 487-501.

30. Slee, E.A.; Adrain, C.; Martin, S.J. Serial killers: Ordering caspase activation events in apoptosis. Cell Death Differ. 1999, 6, 1067-1074. 
31. Srinivasula, S.M.; Ahmad, M.; Fernandes-Alnemri, T.; Alnemri, E.S. Autoactivation of procaspase-9 by Apaf-1-mediated oligomerization. Mol. Cell 1998, 1, 949-957.

32. Slee, E.A.; Adrian, C.; Martin, S.J. Executioner caspase-3, -6, and -7 perform distinct, non-redundant roles during the demolition phase of apoptosis. J. Biol. Chem. 2001, 280, 4663-4673.

33. Kuida, K.; Zheng, T.S.; Na, S.Q.; Kuan, C.Y.; Yang, D.; Karasuyama, H.; Rakic, P.; Flavell, R.A. Decreased apoptosis in the brain and premature lethality in CPP32-deficient mice. Nature 1996, 384, 368-372.

34. Woo, M.; Hakem, R.; Soengas, M.S.; Duncan, G.S.; Shahinian, A.; Kägi, D.; Hakem, A.; McCurrach, M.; Khoo, W.; Kaufman, S.A.; et al. Essential contribution of caspase 3/CPP32 to apoptosis and its associated nuclear changes. Genes Dev. 1998, 12, 806-819.

(C) 2011 by the authors; licensee MDPI, Basel, Switzerland. This article is an open access article distributed under the terms and conditions of the Creative Commons Attribution license (http://creativecommons.org/licenses/by/3.0/). 